Valentina Rapajić

University of Defence

Military Academy $811.111^{\prime} 42$

https://doi.org/10.18485/climb.2017.5.2.ch14

\title{
METADISCOURSE RESOURCES OF SELF-REFERENCE IN MEDICAL CASE REPORTS
}

\section{Summary}

As a metadiscourse resource, self-reference is examined in a corpus of medical case reports (MCRs) published in medical journals in Great Britain, the USA, and Serbia. The practice of medicine entails doctor-patient interaction, and MCRs report the authors' own experience of treating a patient; therefore, expressions of self-reference, unlike in other scientific text-types, are not uncommon. The present paper examines similarities and differences in typology, frequency and distribution of self-reference expressions in MCRs written by native and non-native speakers of English.

Key words: English, metadiscourse, self-reference, medical case report, medical journal

\section{Introduction}

The medical case report (MCR) is "a medical recount of a pathological condition in a single patient" (Helán 2012: 57). More precisely, MCRs are "stories or narratives of the onset, development and treatment of a pathological condition in a single patient" (ibid, 63). They are a vehicle for medical practitioners to share their experiences and insights with peers. Green and Johnson (2000: 52) list a multitude of reasons for publishing a case report, from presenting an unusual or unknown disorder, unusual aetiology, or a challenging differential diagnosis, to describing unusual or puzzling clinical features, improved or unique technical procedures, but also doctors' mistakes; to prompting, disconfirming, or supporting a hypothesis and thus stimulating further research. 
In the hierarchy of evidence on which clinical decision-making is based, case reports are considered the most subjective (Greenhalgh 2001: 39-55). Unlike the impersonal tone of scientific writing, this type of text exhibits, not infrequently, a personal voice of the authors, self-reference being one of the means through which the authors' presence in text is established. "The highly personal nature of a physician's experience of interaction with a patient conveyed in a MCR, even where teams of specialists participate in the diagnosis and treatment, and the authorship of the text may be said to be collective, makes self-reference highly likely." (Rapajić 2018, in press).

In his research on academic writing, Hyland explores self-reference within the framework of metadiscourse. "Metadiscourse is self-reflective linguistic material referring to the evolving text and to the writer and imagined reader of that text" (Hyland 2004: 156). Metadiscoursal resources are the linguistic resources that "organize a discourse or the writer's stance towards either its content or the reader" (Hyland 2000: 109). Distinguishing between interactive metadiscoursal resources (that help to guide the reader through text) and interactional ones (that involve the reader in the argument), Hyland identifies instances of self-reference as belonging to the latter (2004: 169). An overview of Hyland's metadiscoursal resources with brief explanations and examples is given in the table below.

\begin{tabular}{|c|c|c|}
\hline CATEGORY & FUNCTION & EXAMPLES \\
\hline \multicolumn{3}{|c|}{ Interactive resources } \\
\hline Transitions & $\begin{array}{l}\text { express semantic } \\
\text { relation between main } \\
\text { clauses }\end{array}$ & in addition / but / thus / and \\
\hline Frame markers & $\begin{array}{l}\text { refer to discourse acts, } \\
\text { sequences, or text } \\
\text { stages }\end{array}$ & finally / to conclude / my purpose is \\
\hline $\begin{array}{l}\text { Endophoric } \\
\text { markers }\end{array}$ & $\begin{array}{l}\text { refer to information in } \\
\text { other parts of the text }\end{array}$ & noted above / see Fig / in section 2 \\
\hline Evidentials & $\begin{array}{l}\text { refer to source of } \\
\text { information from } \\
\text { other texts }\end{array}$ & according to $X /(Y, 1990) / Z$ states \\
\hline
\end{tabular}


Култура и/или наука

\begin{tabular}{|l|l|l|}
\hline Code glosses & $\begin{array}{l}\text { help readers grasp } \\
\text { meanings of ideational } \\
\text { material }\end{array}$ & namely /e.g. / such as / in other words \\
\hline Interactional resources & $\begin{array}{l}\text { withhold writer's } \\
\text { full commitment to } \\
\text { proposition }\end{array}$ & might / perhaps / possible / about \\
\hline Hedges & $\begin{array}{l}\text { emphasize force or } \\
\text { writer's certainty in } \\
\text { proposition }\end{array}$ & in fact / definitely / it is clear that \\
\hline Boosters & $\begin{array}{l}\text { express writer's } \\
\text { attitude to proposition }\end{array}$ & unfortunately / / agree / surprisingly \\
\hline Attitude markers & $\begin{array}{l}\text { explicitly refer to or } \\
\text { build relationship with } \\
\text { reader }\end{array}$ & consider / note that / you can see that \\
\hline $\begin{array}{l}\text { Engagement } \\
\text { markers }\end{array}$ & $\begin{array}{l}\text { explicit reference to } \\
\text { author(s) }\end{array}$ & I/we / my / our \\
\hline Self-mentions &
\end{tabular}

Table 1. Interactive and interactional metadiscoursal resources. (Hyland 2004: 169).

\section{Objectives}

The aim of this exploratory study is to compare instances of selfreference in MCRs published in British, US, and Serbian medical journals (where the language of publication, English, is not the authors' first language), and to determine, through their typology, frequency, and distribution, whether or not they signal culture-dependent patterns in scientific writing.

\section{Corpus and Method}

The corpus compiled for the purposes of this exploratory study totals 60 MCRs from 6 medical journals. Texts from British Medical Journal of Case Reports (henceforth BMJCR) and Oxford Medical Case Reports (henceforth OMCR) represent British English; texts from American Journal of Case Reports (henceforth AJCR) and Journal of Investigative 
Medicine High Impact Case Reports (JIMHICR) represent American English; and texts from Military Medical and Pharmaceutical Journal of Serbia (Војносанитетски пеглед in Serbian; henceforth MMPJS) and Medical Review (Медицински преглед in Serbian; henceforth MR) represent L2 English in Serbian medical journals published in English. The texts collected for the corpus were published in 2016 and 2017.

The criteria for inclusion in the corpus were accessibility of texts ${ }^{1}$, affiliations of authors, and the country in which the journal is published. All texts in the corpus have multiple authors. To be comparable, all MCRs chosen for the corpus present a single patient whose treatment outcome is favourable.

Word count was performed using T. Cobb's Web VP Classic v. 4 software $^{2}$. The phrases that include self-reference were manually noted and listed. The data obtained in this way were analyzed in terms of their lexicosyntactic type, frequency, and distribution across MCRs in the corpora (British English, American English, L2 English), the subcorpora (defined by the medical journal that was the source for the texts), and in individual MCRs.

\section{Results and Discussion}

Self-reference resources found in these corpora exhibit constructions of predication (with we as the subject in all instances except two, where the subject is the authors) and modification (with the possesssive adjective our in all instances but one, where the possessive pronoun ours is used; both forms are in the first person plural). Hyland's examples of self-reference are exactly of these two types (Table 1). Another type of self-reference resource was also identified on these corpora: reference to the members of medical profession involved in the care of the patient. The table below provides quantitative data from the corpora.

1 BMJCR is partly open access; the other five journals are fully open access.

2 www.lextutor.ca 


\begin{tabular}{|c|c|c|c|c|c|c|c|c|c|c|c|c|c|}
\hline \multirow[b]{2}{*}{$\begin{array}{l}\frac{0}{0} \\
\frac{0}{0} \\
\end{array}$} & \multirow[b]{2}{*}{$\begin{array}{l}00 \\
0 \\
0 \\
0 \\
0 \\
1 \\
0 \\
\\
\end{array}$} & \multirow{2}{*}{ 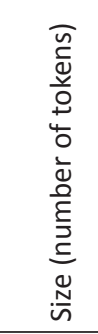 } & \multirow{2}{*}{ 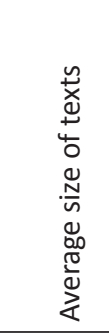 } & \multicolumn{4}{|c|}{$\begin{array}{l}\text { Predication (we ...) } \\
\text { number of instances / } \\
\text { number of instances per } \\
100 \text { tokens }\end{array}$} & \multicolumn{5}{|c|}{$\begin{array}{l}\text { Modification (our ...) } \\
\text { number of instances / number of } \\
\text { instances per } 100 \text { tokens }\end{array}$} & \multirow[t]{2}{*}{ RMP } \\
\hline & & & & 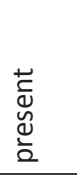 & 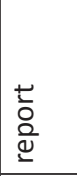 & 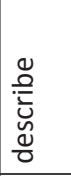 & 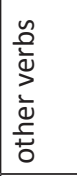 & 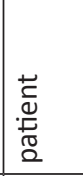 & 心 & 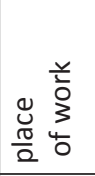 & 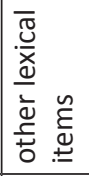 & $\begin{array}{l}\dot{y} \\
\dot{0} \\
+ \\
\end{array}$ & \\
\hline \multirow{2}{*}{$\begin{array}{l}\text { UK } \\
\text { Medical } \\
\text { Journals }\end{array}$} & BMJCR & 13184 & 1318 & 5 & 4 & 4 & 7 & 5 & 11 & 0 & 0 & 1 & 9 \\
\hline & OMCR & 11091 & 1109 & 9 & 2 & 2 & 10 & 11 & 3 & 1 & 2 & 1 & 0 \\
\hline \multicolumn{2}{|c|}{ Total number of self-reference expressions: 87} & 24275 & 1214 & 14 & 6 & 6 & 17 & 16 & 14 & 1 & 2 & 2 & 9 \\
\hline \multicolumn{4}{|c|}{ Normalised values (per 100 tokens): 0.35} & 0.06 & 0.02 & 0.02 & 0.07 & 0.06 & 0.06 & 0.004 & 0.01 & 0.01 & 0.04 \\
\hline \multirow{2}{*}{$\begin{array}{l}\text { US } \\
\text { Medical } \\
\text { Journals }\end{array}$} & AJCR & 17666 & 1767 & 5 & 10 & 3 & 9 & 30 & 7 & 6 & 2 & 6 & 2 \\
\hline & JIMHICR & 15133 & 1513 & 8 & 6 & 5 & 6 & 24 & 17 & 2 & 7 & 5 & 8 \\
\hline \multicolumn{2}{|c|}{ Total number of self-reference expressions: 171} & 32799 & 1638 & 13 & 16 & 8 & 15 & 54 & 24 & 8 & 9 & 14 & 10 \\
\hline \multicolumn{4}{|c|}{ Normalised values (per 100 tokens): 0.49} & 0.04 & 0.05 & 0.02 & 0.04 & 0.16 & 0.07 & 0.02 & 0.03 & 0.04 & 0.03 \\
\hline \multirow{2}{*}{$\begin{array}{l}\text { Serbian } \\
\text { Medical } \\
\text { Journals }\end{array}$} & MMPJS & 15802 & 1580 & 8 & 4 & 1 & 22 & 4 & 2 & 4 & 0 & 0 & 0 \\
\hline & MR & 15224 & 1522 & 6 & 1 & 1 & 12 & 11 & 8 & 5 & 5 & 0 & 16 \\
\hline \multicolumn{2}{|c|}{ Total number of self-reference expressions: 110} & 31026 & 1551 & 14 & 5 & 2 & 34 & 15 & 10 & 9 & 5 & 0 & 16 \\
\hline \multicolumn{4}{|c|}{$\begin{array}{l}\text { Normalised values } \\
\text { (per } 100 \text { tokens): } 0.36\end{array}$} & 0.04 & 0.02 & 0.01 & 0.11 & 0.05 & 0.03 & 0.03 & 0.02 & 0 & 0.05 \\
\hline \multicolumn{4}{|c|}{ Total number of self-reference expressions in the whole corpus: 368} & 41 & 27 & 16 & 66 & 83 & 48 & 18 & 16 & 16 & 35 \\
\hline
\end{tabular}

t.o.k. - to (the best of) our knowledge

RMP - reference to medical professionals

Table 2. Types and frequency of self-reference phrases in the corpora. 
Overall, most self-reference resources were found in the US corpus, almost twice the number found in the UK corpus. The frequency of selfreference in the Serbian L2 English corpus, half-way between the two, is closer to the latter.

In both predication and modification, one lexical choice dominates all others: present and patient, respectively. Other frequent verbs in predication are report and describe, and a high number of various low frequency verbs (e.g. we estimate / recommend / urge caution). In modification, another frequent lexical choice is case. Also found was a relatively small number of other lexical choices (e.g. our aim / data / conclusion). Worth mentioning are phrases denoting the authors' place of work (e.g. our hospital / institution / facility), as well as the phraseme to the (best of) our knowledge (that stands out in the US corpus but was not recorded in the Serbian L2 English corpus) which, due to its conventionalisation, can be treated as a hedging device rather an instance of self-mention. Reference to medical professionals (e.g. the cardiologist, the neuropsychiatry team) was frequent enough to warrant treatment of such expression as a separate type of self-reference.

To highlight similarities and differences between the Serbian L2 English corpus and the native English corpora, normalised frequencies of self-reference resources (phrases, not individual words) are ranked in Table 3 in descending order. 
Култура и/или наука

\begin{tabular}{|c|c|c|c|}
\hline $\begin{array}{l}\text { Self- } \\
\text { reference } \\
\text { instance per } \\
100 \text { tokens }\end{array}$ & UK corpus & US corpus & Serbian L2 English corpus \\
\hline 0.16 & & modification with patient & \\
\hline 0.11 & & & $\begin{array}{l}\text { predication with other } \\
\text { verbs }\end{array}$ \\
\hline \multicolumn{4}{|l|}{0.09} \\
\hline \multicolumn{4}{|l|}{0.08} \\
\hline 0.07 & $\begin{array}{l}\text { predication with other } \\
\text { verbs }\end{array}$ & modification with case & \\
\hline 0.06 & $\begin{array}{l}\text { modification with patient } \\
\text { modification with case } \\
\text { predication with present }\end{array}$ & & \\
\hline 0.05 & & predication with report & $\begin{array}{l}\text { reference to medical } \\
\text { professionals modification } \\
\text { with patient }\end{array}$ \\
\hline 0.04 & $\begin{array}{l}\text { reference to medical } \\
\text { professionals }\end{array}$ & $\begin{array}{l}\text { predication with other } \\
\text { verbs } \\
\text { to the (best of) our } \\
\text { knowledge } \\
\text { predication with present }\end{array}$ & predication with present \\
\hline 0.03 & & $\begin{array}{l}\text { reference to medical } \\
\text { professionals } \\
\text { modification with other } \\
\text { lexical items }\end{array}$ & $\begin{array}{l}\text { modification with case } \\
\text { modification with a } \\
\text { phrase denoting the place } \\
\text { of work }\end{array}$ \\
\hline 0.02 & $\begin{array}{l}\text { predication with report } \\
\text { predication with describe }\end{array}$ & $\begin{array}{l}\text { predication with describe } \\
\text { modification with a } \\
\text { phrase denoting the } \\
\text { place of work }\end{array}$ & $\begin{array}{l}\text { modification with other } \\
\text { lexical items } \\
\text { predication with report }\end{array}$ \\
\hline 0.01 & $\begin{array}{l}\text { to the (best of) our } \\
\text { knowledge } \\
\text { modification with other } \\
\text { lexical items }\end{array}$ & & predication with describe \\
\hline 0.004 & $\begin{array}{l}\text { modification with a } \\
\text { phrase denoting the } \\
\text { place of work }\end{array}$ & & \\
\hline
\end{tabular}

Table 3. Normalised frequencies of self-reference resources in the corpora.

In both Serbian L2 English corpus and UK corpora, predication with verbs other than present, report and describe is the most frequent type of self-reference, although the number of instances in the former is twice 
the number of that in the latter. In the Serbian L2 English corpus, predication with present is equally frequent as in the US corpus (and lower than in the UK corpus), whereas predication with report is equally frequent as in the UK corpus. Of all types of self-reference, predication with describe is the least frequent in the Serbian L2 English corpus. In the US corpus it is one of the two least frequent types of self-reference; in the UK corpus it has almost the same frequency, but as many as three other types of selfreference are even less frequent.

Frequency of modification with patient in the Serbian L2 English corpus is similar to that in the UK corpus, whereas modification with case is significantly less frequent than in the native English corpora. Frequency of modification of expressions denoting the place of work in the Serbian L2 English corpus is similar to that in the US corpus; in the UK corpus, however, there is only one instance of this type of self-reference. No significant similarities exist across the corpora in modification with lexemes other than patient or case.

Self-reference expressions involving the mention of medical professionals are clearly more frequent in the Serbian L2 English corpus than in the native English corpora. On the subcorpora level, interestingly, no instances of this type of self-reference were recorded in two journals, one of them Serbian (MMPJS) and the other British (OMCR), but the number of instances of this type of self-reference in the other Serbian journal $(M R)$ is almost twice the number of instances in the British journal where this type of self-reference was recorded (BMJCR), and almost twice the number of instances in the US corpus, where this type of self-reference is significantly more present in one of the journals (JIMHICR) than in the other (AJCR).

The table below shows different patterns of single or combined types of self-reference in each subcorpus. 
Култура и/или наука

\begin{tabular}{|c|c|c|c|c|c|c|}
\hline \multirow{3}{*}{$\begin{array}{l}\text { Types of self- } \\
\text { reference }\end{array}$} & \multicolumn{6}{|c|}{ Number of MCRs in the corpus } \\
\hline & \multicolumn{2}{|c|}{ UK Corpus } & \multicolumn{2}{|c|}{ US Corpus } & \multicolumn{2}{|c|}{$\begin{array}{l}\text { L2 English Serbian } \\
\text { Corpus }\end{array}$} \\
\hline & BMJCR & OMCR & AJCR & JMHICR & MMPJS & MR \\
\hline no self-reference & 0 & 1 & 0 & 1 & 2 & 0 \\
\hline P only & 0 & 2 & 0 & 0 & 3 & 1 \\
\hline M only & 2 & 0 & 0 & 0 & 0 & 1 \\
\hline RMP only & 0 & 0 & 0 & 0 & 0 & 0 \\
\hline $\mathrm{P}$ and $\mathrm{M}$ & 4 & 7 & 8 & 5 & 5 & 3 \\
\hline $\mathrm{P}$ and $\mathrm{RMP}$ & 1 & 0 & 0 & 0 & 0 & 0 \\
\hline $\mathrm{M}$ and $\mathrm{RMP}$ & 1 & 0 & 0 & 0 & 0 & 0 \\
\hline $\mathrm{P}, \mathrm{M}$, and $\mathrm{RMP}$ & 2 & 0 & 2 & 4 & 0 & 5 \\
\hline $\begin{array}{l}\text { Total (types of } \\
\text { self-reference) }\end{array}$ & \begin{tabular}{|l|} 
P 7 \\
M 9 \\
RMP 4
\end{tabular} & \begin{tabular}{|l|} 
P 9 \\
M 7 \\
RMP 0
\end{tabular} & \begin{tabular}{|l} 
P 10 \\
M 10 \\
RMP 2
\end{tabular} & $\begin{array}{l}\text { P } 9 \\
\text { M } 9 \\
\text { RMP } 4\end{array}$ & $\begin{array}{l}\text { P } 8 \\
\text { M } 5 \\
\text { RMP } 0\end{array}$ & \begin{tabular}{|l|} 
P 9 \\
M 9 \\
RMP 5
\end{tabular} \\
\hline
\end{tabular}

$\mathrm{P}$-self-reference in a predication construction

$\mathrm{M}$ - self-reference in a modification construction

RMP - reference to medical professionals

Table 4. Distribution of types of self-reference in the corpora.

The most represented type of self-reference in the whole corpus is predication self-reference (found in 52 out of 60 texts). Modification self-reference is found in 49 texts, and reference to medical professionals is found in one quarter of the whole corpus (15 texts). At the subcorpus level, domination of predication self-reference is found in OMCR and MMPJS; in three subcorpora the number of texts that contain predication self-reference equals the number of those containing modification selfreference (AJCR, JMHICR, MR). Only in BMJCR do more texts contain modification self-reference than predication self-reference.

The subcorpora exhibit two (AJCR), three (OMCR, JMHICR, MMPJS), four (MR) or as many as five different patterns of self-reference types (BMJ CR).

The coupling of predication and modification type of self-reference is by far the most represented pattern (in 5 out of 6 subcorpora); it is markedly dominant in OMCR and AJCR. The only subcorpus when this combination is superseded by a different pattern is MR (Serbian), where half of the texts combine modification self-reference, predication self-reference, and reference to medical professionals. This last type of-self reference is 
in this paper added to those identified by Helan. It only occurs combined with other types of self-reference. Two subcorpora (the UK OMCR and the Serbian MMPJS) do not contain it at all. Only four out of 60 MCRs contain no self-reference at all.

\section{Conclusion}

Three types of self-reference expressions were found in the corpus of 60 medical case reports: predication self-reference (most notably we present, we report, and we describe), modification self-reference (most notably our patient, our case) and reference to medical professionals (e.g. the cardiologist, the neuropsychiatry team). As findings vary more between the subcorpora within each national corpus (UK, US, and Serbian) than among the national corpora themselves, evidence of culture-dependent characteristics of self-reference usage in medical text reports, based on frequency and distribution alone, is inconclusive.

\section{Corpus}

Stewart-Parker, Emma Patricia, Mustafa Atta, and Sudeendra Doddi. "A Curious Cause of Appendicitis." BMJ Case Reports (2016): bcr2016216150. PMC. Web. 25 Feb. 2018.

Pathak, Himanshu, and Tarnya Marshall. "Post-Streptococcal Reactive Arthritis: Where Are We Now." BMJ Case Reports (2016): bcr2016215552. PMC. Web. 25 Feb. 2018.

Mohla, Aditi et al. "OCT Angiography in the Management of Choroidal Neovascular Membrane Secondary to Sorsby Fundus Dystrophy." BMJ Case Reports (2016): bcr2016216453. PMC. Web. 25 Feb. 2018.

Napier C., E. H. Gan, and S. H. S. Pearce. "Loperamide-induced hypopituitarism". BMJ Case Reports. (2016): bcr-2016-216384 Web. 25. 02. 2018.

Gamble, David T et al. "Takotsubo Cardiomyopathy with Severe Bradyarrhythmia Following Epidural Insertion." BMJ Case Reports 2016 (2016): bcr2016216946. PMC. Web. 25 Feb. 2018.

Kinsella, F. A. M. et al. "Donor-derived mycosis fungoides following reduced intensity haematopoietic stem cell transplantation from a matched unrelated donor". BMJ Case Reports (2017): bcr-2016-216331. Web. 25. 02. 2018.

BMJ 7 Metraiah, El Hakem Abdelkarim et al. "Deceiving Proteins! A Case of Lymphoma and High Creatinine." BMJ Case Reports (2017): bcr2016217946. PMC. Web. 25 Feb. 2018. 
Култура и/или наука

BMJ 8 Valsamis, Epaminondas Markos, and Thomas Edward Glover. "Granulocytic Sarcoma: A Rare Cause of Sciatica." BMJ Case Reports (2017): bcr2016219009. PMC. Web. 25 Feb. 2018.

BMJ 9 Bhagani, Shradha, Conchubhair Winters, and Sulleman Moreea. "Duodenal Variceal Bleed: An Unusual Cause of Upper Gastrointestinal Bleed and a Difficult Diagnosis to Make." BMJ Case Reports (2017): bcr2016218669. PMC. Web. 25 Feb. 2018.

BMJ 10 T. A. Pollak, T. A. and N. Moran. "Emergence of new-onset psychotic disorder following recovery from LGI1 antibody-associated limbic encephalitis". BMJ Case Reports (2017): bcr-2016-218328. Web. 25. 02. 2018.

Noor, Nurulamin M., Krishna Basavaraju, and Dan Sharpstone. "Alcoholic Ketoacidosis: A Case Report and Review of the Literature." Oxford Medical Case Reports 2016.3 (2016): 31-33. PMC. Web. 25 Feb. 2018.

Malley, Tamir, and Edmund Watson. "A Case of Takotsubo Cardiomyopathy after Chemotherapy." Oxford Medical Case Reports 2016.4 (2016): 55-58. PMC. Web. 25 Feb. 2018.

Brinkert, Miriam et al. "An Unusual Case of False-Positive Coronary Artery Calcium Score." Oxford Medical Case Reports 2016.4 (2016): 71-72. PMC. Web. 25 Feb. 2018.

Kotecha, Jalpa, Ajay V. Kamath, and Chetan Mukhtyar. "Behçet's Pulmonary Artery Aneurysms Treated with Infliximab and Monitored with the 6-Min Walk Test." Oxford Medical Case Reports 2016.4 (2016): 94-96. PMC. Web. 25 Feb. 2018.

Gulsin, Gaurav et al. "Takotsubo Cardiomyopathy with Left Ventricular Thrombus Presenting as Critical Limb Ischaemia." Oxford Medical Case Reports 2016.8 (2016): omw051. PMC. Web. 25 Feb. 2018.

Bangera, Sachin et al. "An Unusual Pain in the Hip." Oxford Medical Case Reports 2016.9 (2016): omw072. PMC. Web. 25 Feb. 2018.

Malhotra, Karan et al. "Progressive Foot Drop Caused by below-Knee Compression Stocking after Spinal Surgery." Oxford Medical Case Reports 2016.9 (2016): omw075. PMC. Web. 25 Feb. 2018.

Parsons, Elizabeth et al. "Lessons from Treatment Resistant Hyperlipidaemia." Oxford Medical Case Reports 2016.10 (2016): omw076. PMC. Web. 25 Feb. 2018.

Graham-Brown, M. P. M. et al. "Induction Treatment of Previously Undiagnosed ANCAAssociated Vasculitis in a Renal Transplant Patient with Rituximab." Oxford Medical Case Reports 2016.10 (2016): omw073. PMC. Web. 25 Feb. 2018.

Anwar, Mohammed Omer et al. "Vasospastic Myocardial Infarction Caused by a Slimming Agent-do Not Forget Non-Prescription Drugs." Oxford Medical Case Reports 2017.4 (2017): omx008. PMC. Web. 25 Feb. 2018.

Ola, Olatunde et al. "Left Ventricular Aneurysm May Not Manifest as Persistent ST Elevation on Electrocardiogram." The American Journal of Case Reports 18 (2017): 410-413. PMC. Web. 25 Feb. 2018.

Margolskee, Elizabeth et al. "A Novel Variant $t(1 ; 22)$ Translocation - ins $(22 ; 1)$ (q13;p13p31) - in a Child with Acute Megakaryoblastic Leukemia." The American Journal of Case Reports 18 (2017): 422-426. PMC. Web. 25 Feb. 2018. 
Sherpa, Michael et al. "Comorbid Human Immunodeficiency Virus (HIV) and MuscleSpecific Kinase (MuSK) Myasthenia Gravis: A Case Report and Literature Review." The American Journal of Case Reports 18 (2017): 427-430. PMC. Web. 25 Feb. 2018.

Tasch, James, and Pedro Gonzalez-Zayaz. "Ceftriaxone-Induced Hemolytic Anemia in a Jehovah's Witness." The American Journal of Case Reports 18 (2017): 431-435. PMC. Web. 25 Feb. 2018.

Torrie, Arissa et al. "Regional Anesthesia Did Not Delay Diagnosis of Compartment Syndrome: A Case Report of Anterior Compartment Syndrome in the Thigh Not Masked by an Adductor Canal Catheter." The American Journal of Case Reports 18 (2017): 444-447. PMC. Web. 25 Feb. 2018.

Kashif, Muhammad et al. "A Rare Case of Necrotizing Myopathy and Fibrinous and Organizing Pneumonia with Anti-EJ Antisynthetase Syndrome and Sjögren's Syndrome (SSA) Antibodies." The American Journal of Case Reports 18 (2017): 448453. PMC. Web. 25 Feb. 2018.

Soriano, Paolo K. et al. "A Case of Trigger-Point Injection-Induced Hypokalemic Paralysis." The American Journal of Case Reports 18 (2017): 454-457. PMC. Web. 25 Feb. 2018.

Van Matre, Edward T. et al. "Levetiracetam Pharmacokinetics in a Patient with Intracranial Hemorrhage Undergoing Continuous Veno-Venous Hemofiltration." The American Journal of Case Reports 18 (2017): 458-462. PMC. Web. 25 Feb. 2018.

Sadjadi, Seyed Ali, and Alexander Pi. "Hyperphosphatemia, a Cause of High Anion Gap Metabolic Acidosis: Report of a Case and Review of the Literature." The American Journal of Case Reports 18 (2017): 463-466. PMC. Web. 25 Feb. 2018.

Zhang, Fan et al. "ST-Segment Elevation Myocardial Infarction with Acute Stent Thrombosis Presenting as Intractable Hiccups: An Unusual Case." The American Journal of Case Reports 18 (2017): 467-471. PMC. Web. 25 Feb. 2018.

Mustafa Ali, Moaath, Ana Lucia Ruano Mendez, and Hetty E. Carraway. "Hemophagocytic Lymphohistiocytosis in a Patient With Hodgkin Lymphoma and Concurrent EBV, CMV, and Candida Infections." Journal of Investigative Medicine High Impact Case Reports 5.1 (2017): 2324709616684514. PMC. Web. 25 Feb. 2018.

Gangadharan, Venkat et al. "Anomalous Origin of the Left Coronary Artery From the Pulmonary Artery: An Uncommon Coronary Anomaly With Serious Implications in Adulthood." Journal of Investigative Medicine High Impact Case Reports 5.1 (2017): 2324709616684629. PMC. Web. 25 Feb. 2018.

Hawkins, Kellie L., Edward N. Janoff, and Robert W. Janson. "Resolution of Q FeverAssociated Cryoglobulinemia With Anti-CD20 Monoclonal Antibody Treatment." Journal of Investigative Medicine High Impact Case Reports 5.1 (2017): 2324709616686612. PMC. Web. 25 Feb. 2018.

Aqeel, Masooma et al. "An Unusual Suspect Causing Hypoxemic Respiratory Failure." Journal of Investigative Medicine High Impact Case Reports 5.1 (2017): 2324709616687587. PMC. Web. 25 Feb. 2018.

Acharya, Prakash, Jonathan Ross Ang, and Bernard Gitler. "Ebstein Anomaly With QRS 
Fragmentation on Electrocardiogram." Journal of Investigative Medicine High Impact Case Reports 5.1 (2017): 2324709616688710. PMC. Web. 25 Feb. 2018.

Sutton, S. Scott et al. "Ertapenem-Induced Encephalopathy in a Patient With Normal Renal Function." Journal of Investigative Medicine High Impact Case Reports 5.1 (2017): 2324709616689376. PMC. Web. 25 Feb. 2018.

McDow, Alexandria D. et al. "Portal Vein Thrombosis in the Setting of Newly Diagnosed Cushing's Syndrome." Journal of Investigative Medicine High Impact Case Reports 5.2 (2017): 2324709617703672. PMC. Web. 25 Feb. 2018.

Duzenli, Anthony E., John Dwyer, and Jeanne Carey. "Haemophilus Parainfluenzae Endocarditis Associated With Maxillary Sinusitis and Complicated by Cerebral Emboli in a Young Man." Journal of Investigative Medicine High Impact Case Reports 5.2 (2017): 2324709617704003. PMC. Web. 25 Feb. 2018.

McLeod, Jennifer et al. "Tacrolimus-Associated Dilated Cardiomyopathy in Adult Patient After Orthotopic Liver Transplant." Journal of Investigative Medicine High Impact Case Reports 5.2 (2017): 2324709617706087. PMC. Web. 25 Feb. 2018.

Pujara, Shreya, and Adriana loachimescu. "Prolonged Ketosis in a Patient With Euglycemic Diabetic Ketoacidosis Secondary to Dapagliflozin." Journal of Investigative Medicine High Impact Case Reports 5.2 (2017): 2324709617710040. PMC. Web. 25 Feb. 2018.

Vuković Ercegović G, et al. "Successful usage of intravenous lipid emulsion in treatment of acute verapamil poisoning - A case report". Vojnosanit Pregl 2017; 74(3): 278281. Web. 25 Feb. 2018.

Gvozdenović, Nemanja et al. "Modified technique of the treatment for proximal tibiofibular joint dislocation". Vojnosanitetski pregled 2017; 74(3): 282-286. Web. 25 Feb. 2018.

Radovanović, Zoran et al. "Burkitt lymphoma as a cause of intussusceptions - The significance of positron emission tomography scan in the follow-up". Vojnosanitetski pregled 2017; 74(3): 294-297. Web. 25 Feb. 2018.

Milev, Boško et al. "Abdominal localization of unicentric form of Castleman disease - A case report". Vojnosanitetski pregled 2017; 74(4): 367-370. Web. 25 Feb. 2018.

Čvorović, Ljiljana et al. "Unexpected bony structure in tonsillar fossa during tonsillectomy". Vojnosanitetski pregled 2017; 74(4): 371-373. Web. 25 Feb. 2018.

Zlata Brkić, et al. "Oral rehabilitation of a patient with temporomandibular joint ankylosis caused by ankylosing spondylitis: A case report". Vojnosanitetski pregled 2017; 74(4): 374-377. Web. 25 Feb. 2018.

Nikolić Živorad, et al. "Intraosseous focal venous malformation of the mandibular body: cone beam computed tomography planning followed by piezoelectric knife resection and free bone graft reconstruction". Vojnosanitetski pregled 2017; 74(5): 483-488. Web. 25 Feb. 2018.

Roganović, Branka et al. "Hereditary hemorrhagic telangiectasia associated with inherited thrombophilia". Vojnosanitetski pregled 2017; 74(5): 489-493. Web. 25 Feb. 2018.

Marković, Olivera et al."Hemophagocytic syndrome triggered by intense physical activity and viral infection in a young adult female with three heterozy- 
gous mutations in Munc-18-2". Vojnosanitetski pregled 2017; 74(5): 494497. Web. 25 Feb. 2018.

Dinčić, Dragan et al. "Pulmonary veins isolation in a patient with atrial fibrillation and pronounced vagal response: Is it enough?" Vojnosanitetski pregled 2017; 74(5): 498-501. Web. 25 Feb. 2018.

Jonjev, Živojin et al. "An incidental finding of thymic carcinoma during elective coronary artery bypass grafting". Medicinski pregled 69, 5/6 (2016): 167-169. Web. 25 Feb. 2018.

Ivanov, Igor et al. "First application of automated external defibrilator in Serbia - case report". Medicinski Pregled 69, 7/8 (2016): 237-240. Web. 25 Feb. 2018.

Vicković, Sanja et al. "Anaesthesia for awake brain tumour surgery: case report". Medicinski pregled 69, 9/10 (2016): 295-297. Web. 25 Feb. 2018.

Stošić, Momčilo, Igor Stojanović and Svetlana Mihajlović. "The ligation of the intersphinetric tract procedure of the perianal fistula: case report. Medicinski pregled 69, 9/10 (2016): 298-301. Web. 25 Feb. 2018.

Bjelan, Mladen et al. "Dyke-Davidoff-Masson syndrome - typical imaging features". Medicinski pregled 69, 11/12 (2016): 373-375. Web. 25 Feb. 2018.

Milankov, Miroslav. "Bilateral simultaneous anterior cruciate ligament rupture: a case report and literature review". Medicinski pregled 70, 1/2 (2017): 39-43. Web. 25 Feb. 2018.

Čanković Milenko, et al. "Posterior wall myocardial infarction: a case report". Medicinski pregled 70, 1/2 (2017): 44-47. Web. 25 Feb. 2018.

Stošić Srđan, et al. "Hepatocellular carcinoma presenting with pyrexia and leukocytosis: a case report". Medicinski pregled 70, 1/2 (2017): 48-52. Web. 25 Feb. 2018.

Milošević, Uroš et al. "Central pancreatectomy in surgical treatment of pancreatic insulinoma - a case report". Medicinski Pregled 70, 3/4 (2017): 111-114. Web. 25 Feb. 2018.

Milankov, Olgica et al. "Paracardial cyst in an infant with pleural effusion - a case report". Medicinski Pregled 70, 3/4 (2017): 115-117. Web. 25 Feb. 2018.

\section{References}

Cobb, T. Web Vocabprofile Classic v.4. An adaptation of Heatley, Nation and Coxhead's (2002) Range. Web. 21. 03. 2018.

Green, B. N. and C. D. Johnson. "Writing Patient Case Reports for Peer-reviewed Journals: Secrets of the Trade". Journal of Sports Chiropractic and Rehabilitation 14, 3 (2000): 51-59. Web. 21. 03. 2018

Greenhalgh, T. How to Read a Paper. The Basics of Evidence Based Medicine. London: BMJ Books, 2001. Printed.

Helán, R. Analysis of Published Medical Case Reports: Genre-Based Study. PhD Dissertation. Brno: Masaryk University, 2012. Web. 21. 03. 2018.

Hyland, K. Disciplinary Discourses: Social Interactions in Academic Writing. London: Longman, 2000. Printed. 
Култура и/или наука

Hyland, K. and P. Tse. "Metadiscourse in Academic Writing: A Reappraisal". Applied Linguistics 25, 2 (2004): 156-177.

Rapajić, V. (2018). The Correlation betwen Structural Moves in Medical Case Reports and Metadiscoursal Resource of Self-reference. Book of Proceedings. $4^{\text {th }}$ International Conference on Language for Specific Purposes and Professional Identity. Belgrade: Teacher Education Faculty, University of Belgrade. (in press)

Валентина Рапајић

Министарство одбране

Војна академија Београд

\section{МЕТАДИСКУРСНА СРЕДСТВА САМОПОМИЊАЊА У ПРИКАЗИМА ПАЦИЈЕНТА}

\section{Садржај}

Као метадискурсно средство, самопомињање је проучено у корпусу приказа пацијента објављених у медицинским часописима у Великој Британији, САД и Србији. Лекарска пракса подразумева интеракцију лекара и пацијента, а прикази пацијента извештавају о властитом искуству аутора у лечењу пацијнта; стога изрази самопомињања нису реткост, за разлику од других типова текста у научној литератури. У овом раду разматрају се сличности и разлике у типологији, улесталости и дистрибуцији израза самопомињања у приказима пацијента чији су аутори изворни и страни говорници енглеског језика.

Кључне речи: енглески, метадискурс, самопомињање, приказ пацијента, медициснки часопис 